\title{
Erytroferron - nowy hormon regulujący syntezę hepcydyny
}

\section{Erythroferrone - a new hormone regulating production of hepcidin}

\author{
Edyta Knap, Beata Jakubowska-Solarska, Magdalena Nieśpiałowska \\ Zakład Diagnostyki Hematologicznej, Katedra Diagnostyki Laboratoryjnej, Uniwersytet Medyczny w Lublinie
}

\begin{abstract}
Streszczenie
Żelazo jest metalem niezbędnym do życia, ale zarówno jego niedobór, jak i nadmiar prowadzi do poważnych zaburzeń funkcjonowania organizmu. W utrzymaniu ustrojowej homeostazy żelaza biorq udziat różne biatka. Wiele z nich już doktadnie opisano, a czéść weszła do puli powszechnie stosowanych parametrów stużacych ocenie gospodarki żelazem. W 2014 roku zidentyfikowano nowe biatko, erytroferron, hamujace synteze czasteczki hepcydyny i jednocześnie zwiększajace dostęność zelaza niezbędnego do procesu erytropoezy. Celem niniejszej pracy jest przedstawienie dotychczasowej wiedzy na temat budowy, funkcji oraz potencjalnego zastosowania erytroferronu.
\end{abstract}

Słowa kluczowe: erytroferron, hepcydyna, metabolizm żelaza

Hematologia 2017; 8, 4: 265-270

\begin{abstract}
Iron is an essential bioelement for life, however both a deficiency and overload can lead to serious disorders in body function. Different proteins are involved in maintaining systemic iron homeostasis. Many of these have already been well-described, and some are commonly used markers for assessing iron metabolism. In 2014, a new protein was identified, erythroferrone, which suppresses hepcidin synthesis while increasing the availability of iron that is essential for erythropoiesis. The paper is therefore aimed at presenting current knowledge on the structure, function and the potential uses of erythroferrone.
\end{abstract}

Key words: erythroferrone, hepcidin, iron metabolism

Hematologia 2017; 8, 4: 265-270

\section{Wprowadzenie}

Żelazo jest składnikiem grup prostetycznych wielu białek (hemoglobina, mioglobina, układ cytochromów, katalaza, peroksydaza), determinując ich aktywność oraz pełnione funkcje. W związku $z$ tym żelazo jest niezbędne do prawidłowego przebiegu głównych procesów biologicznych organizmu, takich jak oddychanie komórkowe, synteza i naprawa DNA czy transport tlenu przez hemoglobinę [1,2]. Rów- nocześnie wykazano, że jony żelaza, ze względu na ich labilny charakter (postać utleniona - $\mathrm{Fe}^{3+}$ lub zredukowana - $\mathrm{Fe}^{2+}$ ), mogą katalizować przebieg reakcji Fentona i Habera-Weissa. Żelazo, reagując $z$ nadtlenkiem wodoru, prowadzi do powstania wolnego rodnika hydroksylowego, a produkowane reaktywne formy tlenu uszkadzają białka, lipidy i DNA. Celem utrzymania homeostazy żelaza jest zatem umożliwienie jego wykorzystania przez organizm, ale również ograniczenie toksyczności [3].

Adres do korespondencji: Edyta Knap, Zakład Diagnostyki Hematologicznej, Katedra Diagnostyki Laboratoryjnej, Uniwersytet Medyczny w Lublinie, ul. prof. Antoniego Gębali 6, 20-093 Lublin, e-mail: edyta.knap@umlub.pl 


\section{Metabolizm żelaza i jego regulacja}

Charakterystycznymi cechami gospodarki żelazem u ssaków jest dobrze rozwinięty system regulujący jego absorpcję oraz brak mechanizmu fizjologicznego usuwania tego pierwiastka $z$ ustroju [2]. Dostarczone do organizmu żelazo jest wchłaniane $\mathrm{w}$ dwunastnicy oraz, w mniejszym stopniu, w górnym odcinku jelita cienkiego. Zanim to nastąpi, trójwartościowe żelazo zostaje zredukowane do łatwo przyswajalnej postaci dwuwartościowej. Reakcja zachodzi w silnie kwaśnym $\mathrm{pH}$ i jest katalizowana przez dwunastniczy cytochrom $\mathrm{b}$ - ferroreduktazę [4]. Za absorpcję żelaza ze światła jelita do wnętrza enterocytów odpowiada transporter metali dwuwartościowych (DMT1, divalent metal transporter 1). Z komórek jelita cienkiego, dzięki białku błonowemu - ferroportynie, żelazo przechodzi do krążenia, gdzie ulega ponownemu utlenieniu i po połączeniu $z$ transferyną dociera do odpowiednich tkanek. W szpiku kostnym pierwiastek bierze udział w tworzeniu krwinek czerwonych, a jego niewykorzystana część może być magazynowana w postaci ferrytyny lub hemosyderyny [3].

Ilość żelaza w organizmie jest regulowana kilkoma sposobami. Niedobór pierwiastka musi być uzupełniany z zewnątrz (dieta, suplementy). Natomiast w przypadku nadmiaru żelaza lub podczas infekcji dochodzi do zwiększonej produkcji białek wiążących metal, uwalniania laktoferyny z ziarnistości granulocytów obojętnochłonnych, ograniczonego wchłaniania żelaza pochodzącego $z$ diety i/lub zmniejszonego odzysku pierwiastka ze sfagocytowanych erytrocytów. Dwa ostatnie mechanizmy w dużym stopniu zależą od produkowanej w wątrobie hepcydyny [5]. Jest to białkowy hormon, który po uwolnieniu do krwiobiegu łączy się z $\beta_{2}$-makroglobuliną i jest transportowany do ferroportyny. Pozostała część hepcydyny w połączeniu $z$ albuminą tworzą pulę nieaktywnego białka. Czynna biologicznie hepcydyna inaktywuje ferroportynę poprzez fosforylację reszt tyrozynowych, internalizację, a w końcu degradację w lizosomach. Żelazo zostaje pozbawione głównego transportera komórkowego i jego stężenie w ustroju się zmniejsza [6]. Funkcję hepcydyny potwierdzono w wielu badaniach naukowych. Trwają jednak prace nad poznaniem mechanizmów regulujących syntezę tego białka. Dzięki doświadczeniom, w większości przeprowadzonym na modelach zwierzęcych, udało się odkryć główny szlak regulujący transkrypcję hepcydyny - BMP/Smad. U zwierząt pozbawionych tej drogi sygnalizacyjnej zaobserwowano obniżoną ekspresję hepcydyny, a także pojawiły się objawy poważnego przeładowania organizmu żelazem. W dalszych badaniach dowiedziono, że istnieją również inne, niezależne od szlaku BMP/ /Smad, sposoby erytropoetycznej regulacji stężenia hepcydyny [7, 8]. Wykazano, że ilość hepcydyny zależy od ustrojowych zasobów żelaza, stężenia erytropoetyny (EPO), niedotlenienia organizmu czy obecności stanu zapalnego. Ponadto pojawiły się próby zakwalifikowania czynnika wzrostu i różnicowania 15 (GDF-15, growth differentiation factor 15) oraz białka TWSG-1 (twisted gastrulation protein homolog 1) do grupy czynników regulujących erytropoezę przez wpływ na hepcydynę. Analogiczne znaczenie przypisywano nawet rozpuszczalnemu receptorowi transferyny (sTfR, soluble transferrin receptor). Hipotezy te odrzucono, ponieważ wymienione czynniki nie wpływają w jednoznaczny, znaczący sposób na stężenie żelaza czy aktywność hepcydyny. W ostatnich latach udało się jednak zidentyfikować nową cząsteczkę łączącą proces erytropoezy $z$ wątrobową syntezą hepcydyny $[6,9]$.

\section{Odkrycie erytroferronu}

W 2014 roku na łamach czasopisma „Nature Genetics” pojawił się artykuł [10], w którym po raz pierwszy opisano nowo zidentyfikowany hormon - erytroferron (ERFE). Jest to białko kodowane przez gen ERFE (położony na chromosomie 2), należące do rodziny białek $\mathrm{C} 1 \mathrm{q} / \mathrm{TNF}$ (tumor necrosis factor) i składające się z 354 aminokwasów [11]. Odkrycia tego dokonał zespół naukowców z Uniwersytetu Kalifornijskiego w Los Angeles. W swoich badaniach poszukiwali oni cząsteczek, których stężenie wzrastało i utrzymywało się na wysokim poziomie podczas thumienia wątrobowej produkcji hepcydyny. Szczególną uwagę naukowców zwrócił niescharakteryzowany jeszcze transkrypt Fam132b. Po dokładniejszej analizie generowany przez niego czynnik nazwano erytroferronem, ponieważ pochodzi $z$ komórek prekursorowych linii erytroidalnej i pełni ważną funkcję w metabolizmie żelaza [10]. Jednocześnie, w wyniku niezależnych badań, białko to opisano jako mionektynę oraz później jako CTRP15. Wykazano, że mionektyna jest produkowana głównie przez mięśnie szkieletowe i bierze udział w metabolizmie kwasów tłuszczowych. Autorzy tej pracy nie brali jednak pod uwagę ewentualnej roli szpiku kostnego $\mathrm{w}$ procesie syntezy opisywanej cząsteczki [12]. Dlatego konieczne jest prowadzenie dalszych badań, by wyjaśnić, w jaki sposób tak różne aktywności białka mogą wspólistnieć. Co istotne, w większości dostępnych danych literaturowych 


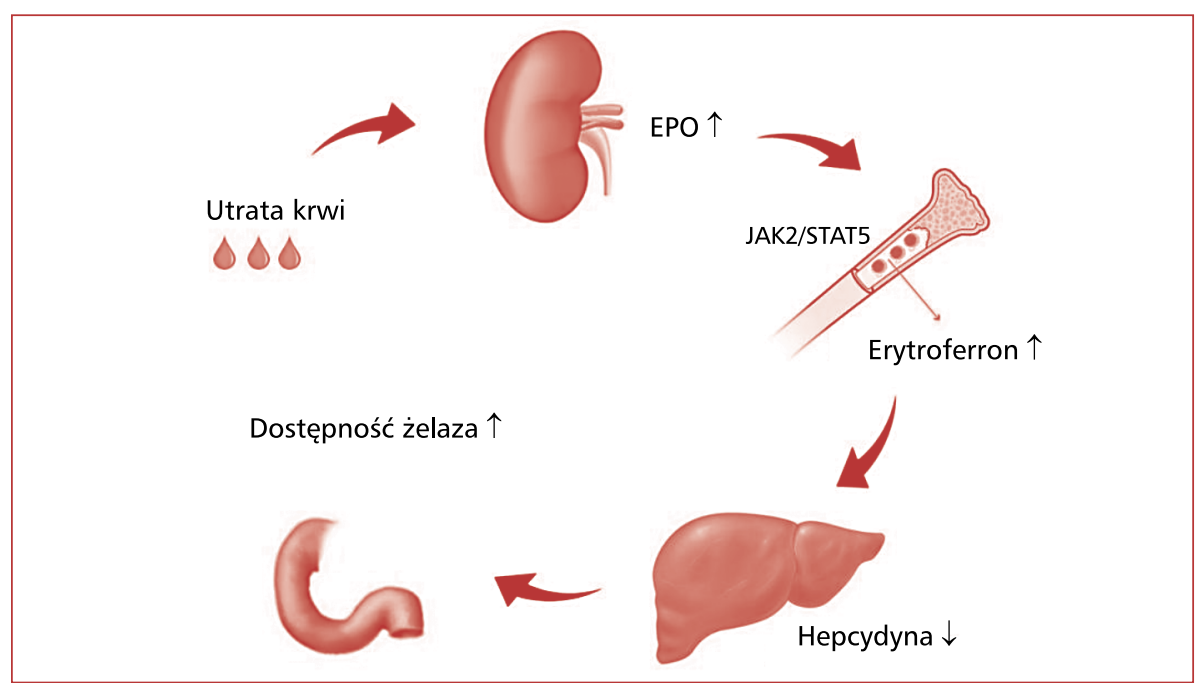

Rycina 1. Szlak regulacyjny erytroferronu; EPO - erytropoetyna

Figure 1. Regulatory pathway for erythroferrone; EPO - erythropoietin

białko kodowane przez transkrypt Fam132b pełni jednak funkcję erytroidalnego regulatora metabolizmu żelaza. Zdecydowano się także ujednolicić nomenklaturę i termin ,erytroferron” przyjęto za powszechnie używany [6].

\section{Synteza ERFE}

W celu zidentyfikowania miejsca syntezy ERFE oceniano tkankową ekspresję Fam132b u myszy przed stymulacją EPO i po takiej stymulacji. Początkowo znaczącą aktywność obserwowano w szpiku kostnym, mięśniach, jądrach, dwunastnicy i jelicie grubym. $Z$ kolei podanie EPO silnie indukowało proces ekspresji w obrębie szpiku kostnego i śledziony dorosłych myszy. Biorąc pod uwagę wyniki przeprowadzonych badań, szpik kostny uznano za główny narząd odpowiedzialny za syntezę ERFE. Ponadto sprawdzono wartość Fam $132 b$ mRNA na każdym etapie trwania erytropoezy. Po upuszczeniu krwi zwiększoną ilość transkryptu wykazano we wszystkich czterech wyodrębnionych populacjach (proerytoblasty, erytroblasty zasadochłonne, polichromatyczne i kwasochłonne), ale największą różnicę w zakresie ekspresji uzyskano w przypadku erytroblastów zasadochłonnych i polichromatycznych. Kolejne badania pozwoliły stwierdzić, w jaki sposób EPO oddziałuje na syntezę ERFE. Udowodniono, że EPO wpływa na ekspresję Fam $132 b$ poprzez wiązanie receptora i aktywację szlaku sygnalizacyjnego JAK2/STAT5, stymulującego proces wytwarzania krwinek czerwonych. Równocześnie nie zaobserwowano zmian w szpikowej produkcji
ERFE w odpowiedzi na niedotlenienie lub obecność uogólnionego stanu zapalnego [10, 13]. Schematyczny model procesu syntezy i wpływu ERFE na organizm przedstawiono na rycinie 1 .

\section{Biologiczna funkcja ERFE}

Odkrycie ERFE jest wynikiem poszukiwań czynnika odpowiedzialnego za regulację stężenia hepcydyny w organizmie. W celu określenia wpływu, jaki wywiera on na hepcydynę, analizowano zmiany jej wątrobowej syntezy w odpowiedzi na utratę krwi. Badane myszy podzielono na trzy grupy - Fam132b $b^{+/+}$, Fam132b $b^{+/-}$oraz Fam132b F $^{-/}$. Po upuszczeniu krwi u myszy typu dzikiego zaobserwowano szybkie, aż 10-krotne zmniejszenie poziomu mRNA hepcydyny, w przeciwieństwie do myszy Fam132b F $^{+-}$oraz Fam $132 b^{-/}$, u których zmiany te były znacznie mniejsze, proporcjonalnie do wartości ERFE w szpiku kostnym i śledzionie. Analogiczny efekt uzyskano, podając zdrowym myszom preparat zawierający rekombinowane białko ERFE. Wśród zwierząt, którym wstrzyknięto jedynie roztwór soli fizjologicznej, nie odnotowano zmian ani w wątrobowej ekspresji mRNA, ani w stężeniu hepcydyny we krwi obwodowej. Udokumentowano również, że w surowicy krwi myszy pozbawionych transkryptu Fam $132 b$ wartość żelaza była istotnie obniżona, w porównaniu $z$ grupą kontrolną. Znamienne wydaje się, że u zwierząt niewykazujących aktywności ERFE indukowana niedokrwistość uległa wyrównaniu, mimo że wyniki badań takich parametrów, jak: stężenie 
hemoglobiny, wartość hematokrytu, średnia objętość krwinki (MCV, mean corpuscular volume), średnia masa hemoglobiny w erytrocycie $(\mathrm{MCH}$, mean corpuscular hemoglobin), odbiegały od normy w większym stopniu i utrzymywały się na niskim poziomie kilka dni dłużej niż u myszy cierpiących na niedokrwistość pokrwotoczną, ale $z$ prawidłową wartością ERFE [10, 14].

Podobne doświadczenia prowadzono także na zwierzętach $z$ zachowanym fizjologicznym stężeniem ERFE, ale $z$ wywołaną laboratoryjnie niedokrwistością hemolityczną. Jiang i wsp. [15] w surowicy krwi badanych myszy odnotowali znaczne zwiększenie stężenia EPO i równie gwałtowny wzrost szpikowej oraz śledzionowej aktywności ERFE. W konsekwencji poziom mRNA hepcydyny uległ stopniowej redukcji. Ponadto udało się udowodnić, że ERFE spełnia swoją biologiczną funkcję, działając bezpośrednio na komórki wątroby [10]. Efekty przeprowadzonych badań potwierdzają, że nowy hormon jest kluczowym, chociaż nie niezbędnym, supresorem ustrojowej syntezy hepcydyny.

\section{Potencjalne możliwości zastosowania ERFE}

Ścisły związek między ERFE, hepcydyną i metabolizmem żelaza skłonił naukowców do poszukiwania roli, jaką może on odgrywać w różnych procesach patologicznych, ze szczególnym uwzględnieniem niedokrwistości. Jedną $z$ powszechnie występujących jest niedokrwistość towarzysząca reakcji zapalnej. Charakteryzuje się ona upośledzoną produkcją krwinek czerwonych, mimo że wartość EPO zazwyczaj pozostaje prawidłowa. Przyczyną zaburzonej erytropoezy jest stymulowana przez cytokiny prozapalne, nieproporcjonalna synteza hepcydyny [16]. Do problemu odnieśli się Kautz i wsp. [14]; w swoich badaniach na myszach, u których za pomocą uśmierconych bakterii Brucella abortus wywoływano uogólniony stan zapalny, wykazali, że u zwierząt pozbawionych ERFE objawy niedokrwistości były bardziej nasilone i utrzymywały się dłużej niż u myszy $z$ typową ekspresją ERFE. Zasugerowano więc, że ERFE może wpływać na poprawę stanu zdrowia osób cierpiących na choroby zapalne $z$ towarzyszącą niedokrwistością, poprzez zmniejszenie stężenia hepcydyny i mobilizację zasobów żelaza niezbędnego do procesu erytropoezy.

Przykładem schorzenia, w przebiegu którego często dochodzi do rozwoju niedokrwistości spowodowanej zmniejszoną dostępnością żelaza, jest przewlekła choroba nerek. Najlepszy sposób wyrównania tego typu niedokrwistości to stosowanie pochodnych EPO. Nowo odkryte białko, ERFE, może się stać kolejnym celem terapeutycznym, łagodzącym przyczynę niedokrwistości i przyspieszającym jej kompensację. Szybkie i skuteczne leczenie niedokrwistości nie tylko poprawia komfort życia pacjenta, ale także obniża ryzyko groźnych powikłań [13]. Udokumentowano, że wysokie wartości hepcydyny i ferrytyny są niezależnymi czynnikami ryzyka chorób układu sercowo-naczyniowego oraz śmiertelności w grupie osób hemodializowanych [17, 18]. Mając na uwadze opublikowane dane, Honda i wsp. [19] próbowali w swojej pracy określić wpływ czynników stymulujących erytropoezę na produkcję ERFE u pacjentów poddawanych zabiegowi hemodializy. Wykazano, że zarówno darbepoetyna $\alpha$, jak i ciągły aktywator receptora erytropoetynowego (CERA, continuous erythropoietin receptor activator) istotnie zwiększały produkcję ERFE, prowadząc jednocześnie do redukcji wartości hepcydyny i mobilizacji ustrojowych zasobów żelaza w grupie badanych osób.

$Z$ dostępnych danych literaturowych wynika, $\dot{z}$ e podwyższone stężenie hepcydyny odnotowano również $\mathrm{w}$ surowicy krwi pacjentek $\mathrm{z}$ nowotworem złośliwym piersi, w porównaniu $z$ grupą kobiet zdrowych oraz $z$ wykrytymi zmianami o charakterze łagodnym. Stopień zaawansowania choroby nie wpływał natomiast na wzrost wartości ERFE. Nie wykazano także korelacji między stężeniem hepcydyny a stężeniem ERFE, EPO czy interleukiny 6 (IL-6). Sugeruje się, że może się to wiązać $z$ ewentualnym osłabieniem wrażliwości hormonu na działanie czynników ustrojowych. $Z$ kolei $\mathrm{w}$ grupie pacjentek $\mathrm{Z}$ rakiem piersi dodatnią korelację zaobserwowano między stężeniem ERFE i hemoglobiny, przy towarzyszącej chorobie niedokrwistości. Autorzy pracy przypuszczają, że rola ERFE w utrzymaniu fizjologicznego stężenia hemoglobiny może zostać zaburzona u chorych na nowotwór. Hipoteza ta wymaga jednak potwierdzenia w kolejnych badaniach klinicznych [20].

Erytroferron, poprzez regulację syntezy hepcydyny i gospodarki żelazem, wspomaga kompensację organizmu w stanie niedokrwistości. W przypadku wrodzonych defektów syntezy hemoglobiny, takich jak talasemia, działanie ERFE przyczynia się jednak do przeładowania organizmu żelazem. W kolejnym doświadczeniu prowadzonym na zwierzęcym modelu $\beta$-talasemii Kautz i wsp. [21] potwierdzili powyższą zależność. Badane myszy wykazywały szczególnie niską wartość hepcydyny, przy bardzo wysokiej ilości ERFE w szpiku kostnym i śledzionie. Zredukowana syn- 
teza hepcydyny jest cechą charakterystyczną dla $\beta$-talasemii i skutkuje zwiększoną absorpcją żelaza $z$ diety. Nadmiar pierwiastka gromadzi się $w$ obrębie różnych narządów, prowadząc do uszkodzeń oksydacyjnych i ciężkich powikłań klinicznych. Proces ablacji transkryptu Fam132b spowodował u myszy wyrównanie poziomu mRNA hepcydyny oraz zmniejszenie ilości odkładającego się w wątrobie i śledzionie żelaza. Brak ERFE złagodził powstałą w wyniku choroby dysfunkcję erytropoetyczną, ale sama niedokrwistość nie uległa poprawie. Przyczyny tego zjawiska upatruje się w hepcydynie, wykazującej prawdopodobnie dodatkowe funkcje w obrębie szpiku kostnego lub w samym ERFE, który mógłby, na przykład działając auto/parakrynnie, hamować dojrzewanie krwinek czerwonych. Nie przeprowadzono jednak badań potwierdzających słuszność stawianych przez autorów hipotez [22].

Ciekawy przykład wpływu ERFE na przebieg choroby zaprezentowano w pracy dotyczącej malarii [23]. Jest to choroba pasożytnicza wywoływana przez zarodźce $z$ rodzaju Plasmodium. Najczęściej występuje w strefach tropikalnej i subtropikalnej, ale ze względu na migrację ludności obszar pojawiania się przypadków malarii ulega poszerzeniu. Zaobserwowano, że w zainfekowanym organizmie dochodzi do szybkiego wzrostu stężenia hepcydyny. Niedokrwistość spowodowana niszczeniem zajętych pasożytami erytrocytów zostaje nasilona przez ograniczoną dostępność żelaza. Gwałtownie obniża się liczba krwinek czerwonych, zmniejszają się stężenie hemoglobiny i wartość hematokrytu. Jednak zwiększona synteza hepcydyny niesie również wiele korzyści dla organizmu gospodarza. Udowodniono, że zmniejszenie puli dostępnego żelaza uniemożliwia wzrost i proliferację pasożytów, co znacznie ogranicza rozwój choroby. Równocześnie w badaniach Latour i wsp. [23] stwierdzono, że w późnej fazie choroby istnieje ujemna zależność między stężeniem hepcydyny a wartością ERFE w szpiku kostnym i śledzionie zarażonych malarią myszy. Ponadto odnotowano, że 13. dnia od zainfekowania zwierzęta $z$ niedoborem ERFE wykazywały znacznie niższą parazytemię niż myszy typu dzikiego. $Z$ przedstawionych danych wynika, że ERFE pośrednio uczestniczy w rozwoju choroby. Utrzymanie co najmniej fizjologicznej produkcji hepcydyny wydaje się więc korzystne w przypadku zarażenia opisanym pasożytem.

\section{Podsumowanie}

Odkrycie ERFE w dużym stopniu ułatwiło zrozumienie mechanizmu regulującego stężenie hepcydyny, co ma istotne znaczenie nie tylko w sta- nie fizjologii, ale również w przebiegu chorób, którym towarzyszy zaburzony metabolizm żelaza. Niezbędne są dalsze badania, uzupełniające aktualną wiedzę dotyczącą roli pełnionej przez ERFE w organizmie oraz możliwości jego potencjalnego zastosowania. Wnioski uzyskane na podstawie doświadczeń przeprowadzonych na modelach zwierzęcych również wymagają potwierdzenia u ludzi. Zapewne wyniki badań uzyskanych w ciągu najbliższych lat pozwolą zweryfikować słuszność hipotez postawionych przez autorów prac wymienionych w niniejszej publikacji.

\section{Piśmiennictwo}

1. Kautz L. Lérythroferrone, un régulateur érythroïde du métabolisme du fer. Médecine/Sciences. 2014; 30(10): 834-836, doi: 10.1051/medsci/20143010005.

2. Lipiński P, Starzyński R, Styś A, et al. Heme metabolism as an integral part of iron homeostasis. Post Hig Med Dośw. 2014; 68: 557-570, doi: 10.5604/17322693.1102284.

3. Wierzbicka D, Gromadzka G. Ceruloplasmin, hephaestin and zyklopen: the three multicopper oxidases important for human iron metabolism. Post Hig Med Dośw. 2014; 68: 912-924, doi: 10.5604/17322693.1111136.

4. Artym J. Udział laktoferryny $\mathrm{w}$ gospodarce żelazem $\mathrm{w}$ organizmie. Część I. Wpływ laktoferryny na wchłanianie, transport i magazynowanie żelaza. Post Hig Med Dośw. 2008; 62: 599-611.

5. Sokołowska E, Klimek J. Hepcydyna — hormon uczestniczący w regulacji metabolizmu żelaza w organizmie. Post Biol Komórki. 2007; 34: 15-30.

6. Lawen A. Is erythroferrone finally the long sought-after systemic erythroid regulator of iron? World J Biol Chem. 2015; 6(3): 78-82, doi: 10.4331/wjbc.v6.i3.78, indexed in Pubmed: 26322167.

7. Arosio P. New signaling pathways for hepcidin regulation. Blood. 2014; 123(10): 1433-1434, doi: 10.1182/blood-2014-01-548594, indexed in Pubmed: 24627545.

8. Camaschella C, Pagani A, Nai A, et al. The mutual control of iron and erythropoiesis. Int J Lab Hematol. 2016; 38 Suppl 1: 20-26, doi: 10.1111/ijlh.12505, indexed in Pubmed: 27161430.

9. Filipczyk L, Król P, Wystrychowski A. Hepcydyna - hormon wątrobowy kontrolujący homeostazę żelaza. Forum Nefrol. 2010; 3: 233-242.

10. Kautz L, Jung G, Valore EV, et al. Identification of erythroferrone as an erythroid regulator of iron metabolism. Nat Genet. 2014; 46(7): 678-684, doi: 10.1038/ng.2996, indexed in Pubmed: 24880340 .

11. https://www.ncbi.nlm.nih.gov/gene/151176 (26.04.2017).

12. Seldin MM, Peterson JM, Byerly MS, et al. Myonectin (CTRP15), a novel myokine that links skeletal muscle to systemic lipid homeostasis. J Biol Chem. 2012; 287(15): 11968-11980, doi: 10.1074/ /jbc.M111.336834, indexed in Pubmed: 22351773.

13. Łukaszczyk E, Małyszko J. Żelazo w chorobach nerek. Kosmos. 2014; 63: 367-371.

14. Kautz L, Jung G, Nemeth E, et al. Erythroferrone contributes to recovery from anemia of inflammation. Blood. 2014; 124(16): 2569-2574, doi: 10.1182/blood-2014-06-584607, indexed in Pubmed: 25193872.

15. Jiang X, Gao M, Chen Y, et al. EPO-dependent induction of erythroferrone drives hepcidin suppression and systematic iron absorption under phenylhydrazine-induced hemolytic anemia. Blood 
Cells Mol Dis. 2016; 58: 45-51, doi: 10.1016/j.bcmd.2016.02.005, indexed in Pubmed: 27067488.

16. Cucuianu A, Patiu M, Trifa AP, et al. Redistribution of iron towards deposits in erythroblastopenic anemia as a consequence of decreased erythroferrone production. Med Hypotheses. 2014; 83(5): 530-532, doi: 10.1016/j.mehy.2014.09.008, indexed in Pubmed: 25267320 .

17. Kuragano T, Shimonaka Y, Kida A, et al. Determinants of hepcidin in patients on maintenance hemodialysis: role of inflammation. Am J Nephrol. 2010; 31(6): 534-540, doi: 10.1159/000312381, indexed in Pubmed: 20484891.

18. van der Weerd NC, Grooteman MPC, Bots ML, et al. CONTRAST Investigators. Hepcidin-25 is related to cardiovascular events in chronic haemodialysis patients. Nephrol Dial Transplant. 2013; 28(12): 3062-3071, doi: 10.1093/ndt/gfs488, indexed in Pubmed: 23147161.

19. Honda H, Kobayashi Y, Onuma S, et al. Associations among erythroferrone and biomarkers of erythropoiesis and iron metabolism, and treatment with long-term erythropoiesis-stimulating agents in patients on hemodialysis. PLoS One. 2016; 11(3): e0151601, doi: 10.1371/journal.pone.0151601, indexed in Pubmed: 26978524.

20. Ciniselli CM, De Bortoli M, Taverna E, et al. Plasma hepcidin in early-stage breast cancer patients: no relationship with interleukin-6, erythropoietin and erythroferrone. Expert Rev Proteomics. 2015; 12(6): 695-701, doi: 10.1586/14789450.2015.1099436, indexed in Pubmed: 26496240.

21. Kautz L, Jung G, Du X, et al. Erythroferrone contributes to hepcidin suppression and iron overload in a mouse model of $\beta$-thalassemia. Blood. 2015; 126(17): 2031-2037, doi: 10.1182/ /blood-2015-07-658419, indexed in Pubmed: 26276665.

22. Moura IC, Hermine O. Erythroferrone: the missing link in $\beta$-thalassemia? Blood. 2015; 126(17): 1974-1975, doi: 10.1182/ /blood-2015-09-665596, indexed in Pubmed: 26494918.

23. Latour C, Wlodarczyk MF, Jung G, et al. Erythroferrone contributes to hepcidin repression in a mouse model of malarial anemia. Haematologica. 2017; 102(1): 60-68, doi: 10.3324/ /haematol.2016.150227, indexed in Pubmed: 27658439. 